\title{
Entrepreneurial Success, Evidence from SMEs of Lahore, Pakistan
}

\author{
Ammar Yasir Jafary \\ Business School, University of Central Punjab, Pakistan \\ ammar.yasir95@yahoo.com
}

Qais Aslam., PhD

Business School, University of Central

Punjab,Pakistan

\begin{abstract}
The study aimed to test the role of access to finance, innovativeness, market orientation and strategic orientation on the entrepreneurial success of SMEs. For this purpose, data has collected form 380 SMEs, operating in Lahore, Pakistan. Primarily data has analyzed in SPSS 22 to check the normality and Multicollinearity and then, Structure Equation Modeling (SEM) was applied using Smart PLS-3. The findings revealed that access to finance, market orientation has positive and significant relationship to the entrepreneurial success of SMEs. Moreover, results also affirms that innovativeness and strategic orientation has significant but negative impact on the entrepreneurial success of SMEs. This study provides the valuable inputs to the practitioners, policy makers and entrepreneurs.
\end{abstract}

Keywords: Access to Finance, Innovativeness, Market Orientation, Strategic Orientation, Small and Medium Enterprises, Entrepreneurial Success, Structural Equation Modeling

\section{Introduction}

SMEs is important to the growth of an economy as these SMEs not only show a distinct part in the employment generation but also help in promoting and improving the existing industrial structure and economic growth around the world. The role of SMEs in the developed economies is considered as a key to boosting the economic growth (Long \& Dong, 2017). Small Medium-Sized Enterprises (SMEs) are considered as economic tool for any growing economy. In the current era, small business is the reason of poverty alleviation and economic stability (Maksimov, Wang, \& Luo, 2017). More than 90 percent of total businesses in the world are SMEs. Entrepreneurial activities help in enhancing economic activity and at the same time creates employment opportunity in the country as well (Ayandibu \& Houghton, 2017).The performance of the SME's can contribute in the growth of the economy, such as growth in the GDP, per capita income, employment opportunities, new markets, exports and new enterprises (Pulka, Ramli, \& Bakar, 2018).

While viewing in the context of Pakistan, entrepreneurship plays an integral role in the economy of Pakistan because contribution of SME was $40 \%$ in the GDP of Pakistan. However, unlike other developing economies, SME sector has not yet gained that much importance in the country. Although SME's constitute about $90 \%$ of total enterprises of Pakistan (SMEDA, 2016). Pakistan's economic development that greatly depends upon the success of small and medium enterprises (Bagh, Arif, Liaqat, \& Razzaq, 2017). Almost 3.2 million small and medium enterprises are working in Pakistan. Approximately $65 \%$ SMEs working in Punjab, $18 \%$ in Sindh, whereas $14 \%$ of in KPK and only $3 \%$ of SMEs are working in Islamabad and Baluchistan(SMEDA., 2017). Out of 65\% of SMEs in Punjab, $14 \%$ of SMEs are working in Lahore.

Since the last 15 years economy is facing downturn so overall businesses in Pakistan are facing challenges for the survival, as Pakistan is ranked 137 as compared to 191 countries in 2018 in terms of ease of doing businesses and as per global entrepreneurship index 2018 Pakistan is ranked 120 as compared to 137 countries (World Bank (IBRD), 2018). It indicates that other countries in the world or particularly in South Asia are moving faster as compared to Pakistan (Sarfraz, 2018). Some recent studies showed that a large number of newly established small and medium enterprises failed within first five years of their startup (Kuratko D. F., 2016).

Studies indicate that Small and medium enterprises face a great threat. Pakistan's low entrepreneurial success is a problem that deserves attention.

Hence, the current study is going to analysis that why SMEs fails by testing the impact of access to finance, innovativeness, market orientation and strategic orientation on the performance of SMEs, market orientation, and strategic orientation answer why some firms are more successful as compared to others and their impact on the success of Small \& Medium Enterprises in Pakistan.

The objectives of this research are as follows:

1. To analysis the impact of access to finance on the entrepreneurial success of Small \& Medium Enterprises in Lahore

2. To analysis the impact of innovativeness on the entrepreneurial success of Small \& Medium Enterprises in Lahore.

3. To analysis the impact of market orientation on the entrepreneurial success of Small \& Medium Enterprises in Lahore

4. To analysis the impact of strategic orientation on the entrepreneurial success of Small \& Medium Enterprises in Lahore.

The study is carried out in the industrial city of Lahore. Lahore contributes almost 14\% toward Pakistan's economy (Mir, Naimi, \& Rosylin, 2016). Total number of the firm, which comes under the bracket of SMEs, are 34006 out of which a sample of 380 collected according to (Krejcie \& Morgan, 1970; Hair, Anderson, Tatham, \& William, 1986).

In this research questionnaire, technique used and the instrument is adapted from different relevant research. (Hair Jr, Wolfinbarger, Money, Samouel, \& Page, 2015). To measure the variables, access to finance, innovativeness,

The current issue and full text archive of this journal is available at www.jraspublications.org/index.php/JRAS/issue/archive Journal of Research in Administrative Sciences (JRAS)

VIII(II), 16-26, ISSN: 2664-2433 
market and strategic orientation towards entrepreneurial success was measured through a 5-point Likert scale. The questionnaire was adopted from similar research.

\section{Literature Review}

\section{Entrepreneurial Success}

A number of variables are taken to examining the entrepreneurial success (Fouzdar \& Sachdev, 2017). Entrepreneurial success is often studied in various studies but the different authors take success in a different manner. Different authors Taormina and Kin-Mei Lao, (2007); Dafna, (2008) and Karadag, (2017), define entrepreneurial successventure that survives for at least three years is considered as an entrepreneurial success. Whereas, majority of researchers emphasize that a firm that survive more than five years is considered as successful.

Access to Finance

Mostly success of SME's is depending upon the ability of the firm to generate internal as well as external finance (Caglayan \& Demir, 2014). Thus, we can say access to finance is one of the factors that determined the future success of a venture (Khan, 2015).

Lee, Sameen, and Cowling (2015) Observed that the shortage of cash flow of small and medium enterprises can only be solved by the external access to finance. Finance is needed to small firm to enlarge their operation, new product development and for the growth of the firms.

\section{Market Orientation}

The market orientation culture is considered a key asset for firms which has been expressly said by (McKenny, Short, Ketchen Jr, Payne, \& Moss, 2018; Jogaratnam, 2017). In respect to enterprise growth and learning orientation Perez Luno, Saparito, and Gopalakrishnan, (2016) observed that market orientation is the stronger tool to measure the success to an enterprise. Similarly, Lonial and Carter, (2015) and Jogaratnam, (2017) pointed out that market orientation is the best strategic capabilities in predicting the entrepreneurial success. Liao, Chang, Wu, and Katrichis, (2011) also said that market orientation is the only tool that consistently explains the firm performance and its success across different countries.

\section{Strategic Orientation}

Strategic orientation is defined as the process of learning new policies with the passage of time and have complete knowledge about the pros and cons of such strategy (Altinay, Madanoglu, De Vita, Arasli, \& Ekinci, 2016). It shows that researchers consider strategic orientation extensively. Studies have been conducted on strategic orientation by different authors. According to Chahal, Dangwal, and Raina, (2016) market orientation and strategic orientation have a significant impact on the small and medium enterprises performance. It is further said that both the independent variables have a direct impact on the dependent variable. Similarly, there are some recent studies, which use learning orientation, market orientation, strategic orientation, network orientation, entrepreneurial orientation, technology orientation as a strategic orientation by a firm (Hakala \& Kohtamäki, 2011; Hakala H. , 2015; Mu \& Di Benedetto, 2011).

\section{Innovativeness}

Many researchers have identified that innovativeness has an impact on the performance of entrepreneurs and classified the concept of the innovativeness in process innovation, product innovation and technology innovation (Sezen \& Cankaya, 2013; Ar, 2012). Moreover, this aspect also supports organization learning, the more an organization learns, the more an organization is able to perform well. According to Wassmann, et al., (2016), new product introduction and changes in product/service lines reflect product innovation results rather than the firm's disposition toward innovativeness.

The part of advancement in entrepreneurial firms is frequently viewed as an important factor in encouraging success of a firm, offering new items with high-profit potential, and upgrading overall value of the firm (Prajogo, 2016; Kuratko D. F., 2009). Innovativeness encourages the advancement of new hierarchical schedules and the disclosure of exceptional ways to deal with innovations, items, or procedures, which surely builds up the firm-particular abilities of these organization. SMEs use such opportunities to create and execute achievement innovations that can be utilized to improve organization performance (Li, Qian, \& Qian, 2015).

\section{Underpinning Theory (Resource Based View)} and (Resource Dependency Theory)

According to Resource-Based View given by the Wernerfelt, (1984) and shows that access to finance, innovativeness, market orientation and strategic orientation enable the firm to be successful, considered as RBV Theory. (Hillman, Withers, \& Collins, 2009). Resource Dependency Theory Resource Dependency Theory given by by the Preffer and Salancik, (1978), includes the external factor which are outside to the company. Such resources includes Innovativeness, which have the effect on the success of the compnay.

\section{Analysis and Software}

Viewing the nature of study, SEM-PLS was applied to see the impact of access to finance, innovativeness, market and strategic orientation on entrepreneurial success by using Smart PLS software.

\section{Results and Findings}

Out of a34,008 total, population of SMEs (Lahore chamber of Commerce), asample of 380 was derived according to the formula given by (Krejcie \& Morgan, 1970). Response rate of the respondents was $71 \%$.

\section{Assessment of Normality}

Assessment of normality is very important where multivariate analysis is carried out in the study (Zanetsie, Adomah, Chongsi, Ngeme-Ndie, \& Faes, 2016). It is very difficult to assess or to assure the normality of the data or the effectiveness of the data. However, the value of kurtosis and skewness that shows the normality in the data for all the variable is acceptable which is $<3$ and $>8$. The value of skewness is shown in the table 5. In the similar way the value of kurtosis is also shown in the table that is not exceeding from the acceptable level. Therefore, it is concluded that data is normally distributed as shown the values in the table.

Table 1: Assessment of Normality

\begin{tabular}{lllll}
\hline Variables & Mean & Std. Deviation & Skewness & Kurtosis \\
\hline AF & 3.96 & .988 & -.926 & .479 \\
IN & 3.87 & 1.133 & -.968 & .214 \\
MO & 3.82 & 1.125 & -.831 & -.020 \\
SO & 3.94 & .961 & -.857 & .426 \\
ES & 3.87 & 1.065 & -.785 & -.076
\end{tabular}

\section{Assessment of Multicollinearity}

When dependent variable and independent variables are highly correlated, the problem of Multicollinearity occurs. (Hair, Sarstedt, Ringle, \& Mena, 2014). It is very difficult to interpret the results of impact of independent variables on the dependent variables. In this aspect, that it necessary to check Multicollinearity before doing the analysis if it is not checked it may affect the results. Therefore, this assessment cannot be ignored as this problem may change the results of the impact of independent variable on the dependent variable. Multicollinearity is due to the high correlation between the independent variables. However, by removing the problem of Multicollinearity you may face the lower value of R-square, which is not a big problem it shows the real value of explaining the dependent variable by the independent variables.

Most common test to assess the Multicollinearity issue is correlation matrix (Clark Jr, 2013). In table 6, which shows the inter correlation between the independent variable. Based on data collected the result of correlation is shown that there is no Multicollinearity between the independent variables. If the value of coefficient of correlation is more than 0.90 its mean that there is the issue of correlation exist. The values are shown in the table below.

\begin{tabular}{llllll}
\hline \multicolumn{7}{l}{ Table 2: Correlations Matrix } & & & \\
\hline Variables & AF & ES & IN & MO & SO \\
AF & 1 & & & & \\
ES & 0.222 & 1 & & & \\
IN & 0.860 & 0.401 & 1 & & \\
MO & 0.290 & 0.730 & 0.367 & 1 & \\
SO & 0.436 & 0.261 & 0.354 & 0.473 & 1 \\
\hline
\end{tabular}


Note: AF: Access to Finance, IN: Innovativeness, MO: Market Orientation, SO: Strategic Orientation, ES: Entrepreneurial Success. Table 3 Variance Inflation factor

\begin{tabular}{ll}
\hline Items & VIF \\
\hline AF1 & 9.308 \\
AF2 & 3.470 \\
AF4 & 2.192 \\
AF5 & 5.767 \\
AF6 & 2.276 \\
ES1 & 7.563 \\
ES2 & 6.056 \\
ES3 & 3.980 \\
ES4 & 4.307 \\
ES5 & 8.160 \\
IN2 & 1.124 \\
IN4 & 2.102 \\
IN5 & 2.250 \\
MO1 & 1.783 \\
MO2 & 2.368 \\
MO3 & 2.071 \\
MO4 & 4.449 \\
MO5 & 4.775 \\
SO1 & 2.102 \\
SO2 & 4.257 \\
SO3 & 2.988 \\
SO5 & 3.805 \\
SO6 & 2.859 \\
SO7 & 3.164 \\
\hline &
\end{tabular}

Multicollinearity checked in this study by Variance Inflation Factor (VIF) and tolerance value. Variability in the construct that is not define by the independent variable is known as tolerance while the opposite to the VIF indicator (Gomez, Perez, Lopez Martin, \& Garcia, 2016). Tolerance value should be more than 0.10 and the value of VIF should be less than 10 shows that there is no problem of Multicollinearity. The following table shows the value of tolerance, which is more than 0.10 , and the value of VIF is not exceeding by 10 . This shows that the problem of Multicollinearity does not exist in this data. Multicollinearity is examined before doing any further analysis. The problem of Multicollinearity and outlier is not found in this analysis.

\section{Evaluation of PLS-SEM Results}

Partial least square and structural equation model PLS-SEM was used to analyze the both model outer model as well as inner model. This model was use to analyze the effect of the independent variables on the dependent variable. This study includes the four independent variables (access to finance, innovativeness, market orientation and strategic orientation) where as one dependent variable (entrepreneurial success).

\section{The Measurement Model}

The measurement model is the first step in the analysis of PLSSEM. The model explains that how factors load theoretically associate with construct. Further, it also shows that there is no issue of reliability and validity in the instrument.

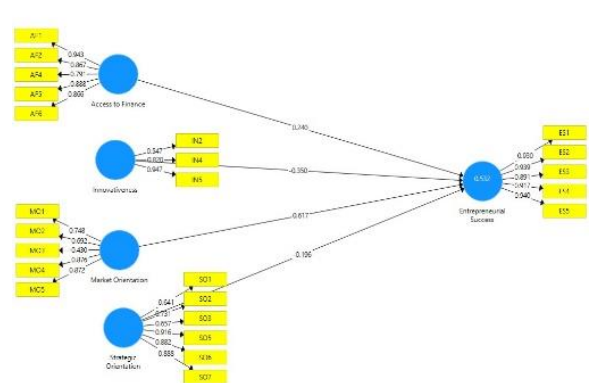

Figure 1: Measurement Model

The table below explains the outer loading of all the factors

Table 4: Outer loading of Access to Finance

\begin{tabular}{|l|l|l|}
\hline Variables & Items & Loadings \\
\hline AF & AF1 & 0.943 \\
\hline & AF2 & 0.867 \\
\hline & AF4 & 0.791 \\
\hline & AF5 & 0.888 \\
\hline & AF6 & 0.866 \\
\hline
\end{tabular}

Note: AF: Access to Finance

Table 5: Outer loading of Innovativeness

\begin{tabular}{|l|l|l|}
\hline Variables & Items & Loadings \\
\hline IN & IN2 & 0.547 \\
\hline & IN4 & 0.820 \\
\hline & IN5 & 0.947 \\
\hline
\end{tabular}

Note: IN: Innovativeness

Table 6: Outer loading of Market Orientation

\begin{tabular}{|l|l|l|}
\hline Variables & Items & Loadings \\
\hline MO & MO1 & 0.748 \\
\hline & MO2 & 0.692 \\
\hline & MO3 & 0.430 \\
\hline & MO4 & 0.876 \\
\hline & MO5 & 0.872 \\
\hline
\end{tabular}

Note: MO: Market Orientation

Table 7: Outer loading of Strategic Orientation

\begin{tabular}{|l|l|l|}
\hline Variables & Items & Loadings \\
\hline SO & SO1 & 0.641 \\
\hline & SO2 & 0.731 \\
\hline & SO3 & 0.657 \\
\hline & SO5 & 0.916 \\
\hline & SO6 & 0.882 \\
\hline
\end{tabular}

Note: SO: Strategic Orientation

Table 8: Outer loading of Entrepreneurial Success

\begin{tabular}{|l|l|l|}
\hline Variables & Items & Loadings \\
\hline ES & ES1 & 0.930 \\
\hline & ES2 & 0.939 \\
\hline & ES3 & 0.891 \\
\hline & ES4 & 0.917 \\
\hline & ES5 & 0.940 \\
\hline
\end{tabular}

Note: ES: Entrepreneurial Success

Validity and reliability are considered as a strong criterion to evaluate the model in the PLS-SEM (Hair Jr, Sarstedt, Hopkins, \& G. Kuppelwieser, 2014). After seeing the validity through outer loading next thing to do is to check the reliability of all the variables. Table 13 shows the reliability of all the variables and the value of Cronbach's Alpha. The value of Cronbach's Alpha is used to evaluate the reliability of the variables and the results of Cronbach's Alpha are shown in the table 13 . The table the value of $\mathrm{AF}$ is 0.922 , similarly the value of IN is 0.687 , the value of MO is 0.787 ,

the value of SO is 0.894 and the value of ES is 0.957 . As stated in the table the value of all variables is above the acceptable level which is 0.60 (Asad, Shariff, \& Alekam, 2016). 
Table 9: Cronbach's Alpha

\begin{tabular}{|l|l|}
\hline Variable & Cronbach's Alpha \\
\hline AF & 0.922 \\
\hline IN & 0.687 \\
\hline MO & 0.787 \\
\hline SO & 0.894 \\
\hline ES & 0.957 \\
\hline
\end{tabular}

Note: AF: Access to Finance, IN: Innovativeness, MO

Market Orientation, SO: Strategic Orientation, ES:

Entrepreneurial Success.

Reliability is another important factor before doing the analysis to find the reliability, convergent validity is another important factor. Convergent validity can be explained as the measurement of similar constructs that are relates and connected with each other (Hair, Sarstedt, Ringle, \& Mena, 2014). This can be measure through the average variance extracted (AVE) the threshold value of AVE is considered as more than 0.50 is considered as appropriate and considered as there is validity among the variables (Henseler, Ringle, \& Sarstedt, 2015).

Table 10: Average Variance Extracted

\begin{tabular}{|c|c|}
\hline Variable & Average Variance Extracted \\
\hline AF & 0.761 \\
\hline IN & 0.623 \\
\hline MO & 0.550 \\
\hline SO & 0.631 \\
\hline ES & 0.853 \\
\hline
\end{tabular}

Af: Access to Finance, IN: Innovativeness, MO:

Market Orientation, SO: Strategic Orientation, ES Entrepreneurial Success.

The value of average variance extracted shown above indicate that all the variables values are above than the acceptable level which is 0.50 . The value of AVE calculated for AF is 0.761 , similarly the value of IN is 0.623 , the value of MO is 0.550 , the value of SO is 0.631 and the value of ES is 0.853 which are all above the 0.50 and ensure validity in the results.

After this, there is no need to evaluate the outer validity further and the reliability of the external consistency now the need to find out the internal consistency. For this purpose, the tool used is known as composite reliability. This is used to ensure the internal consistency the value of composite lies between 0 and 1 and to ensure the validity value of Composite reliability should not be less than 0.60 (Henseler, Ringle, \& Sarstedt, 2015). However, some researchers emphasize on having the value of composite reliability more than 0.70 , which is considered as more desirable. The results of composite reliability are shown in the table 15 and the value of allvariable is more than the recommended value.

Table 11: Composite Reliability

\begin{tabular}{|c|c|}
\hline Variable & Composite Reliability \\
\hline AF & 0.941 \\
\hline IN & 0.826 \\
\hline MO & 0.853 \\
\hline SO & 0.909 \\
\hline ES & 0.967 \\
\hline
\end{tabular}

Note: AF: Access to Finance, IN: Innovativeness, MO: Market Orientation, SO: Strategic Orientation, ES: Entrepreneurial Success.

The ability to measure only one variable is known as discriminant validity of the variable (Voorhees, Brady, Calantone, \& Ramirez, 2016). The value of discriminant validity is taken by taking the square root of average variance extracted with any other construct than discriminant validity recognized (Henseler, Ringle, \& Sarstedt, 2015). The value taken are shown in the table 16.

Table 12: Discriminant Validity

\begin{tabular}{llllll}
\multicolumn{7}{c}{ Tariables } & AF & ES & IN & MO & SO \\
\hline AF & 0.872 & & & & \\
ES & -0.219 & 0.923 & & & \\
IN & 0.756 & -0.363 & 0.789 & & \\
MO & -0.196 & 0.670 & -0.244 & 0.742 & \\
SO & 0.379 & -0.230 & 0.354 & 0.378 & 0.794 \\
\hline
\end{tabular}

Note: AF: Access to Finance, IN: Innovativeness, MO:

Market Orientation, SO: Strategic Orientation, ES: Entrepreneurial Success.

Results of measurement model indicate good findings with the evidence of validity and reliability in the results. Evaluation of the structural model inner model is carried out for further analysis.

\section{The Structural Model}

As shows in the previous part of measurement model that validity and reliability is measured in the measurement model after the evaluation of measurement model next thing to do is to examine the structural model (inner model). In structural model the basic purpose is to check the hypothesis with direct relationship of independent variables with independent variable.

\section{Direct Relationships}

This part of analysis initiates with the measurement of direct relationship of all variables. In this part of analysis, the major important thing was to conduct the testing of hypothesis. This part of analysis gives the clear picture of detailed hypothesis testing. Direct relationship was checked initially to find out the size of the path coefficient through PLS-SEM Algorithm and the sign with the path coefficient determine the nature of relationship among the variables. To analyze the significance of the relationship among the variables Smart PLS3 used. In the model direct relationship among independent variable $\mathrm{AF}$, IN, MO, SO was evaluated on the dependent variable ES. To find out the path coefficient, Algorithm was run. The result of PLS is show in the figure 3 as shown in the picture the values of factor loading is shown in three.

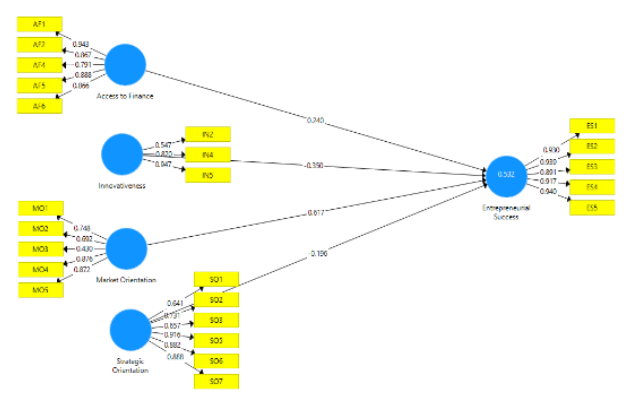

Figure 2: PLS Algorithm Direct Relationship

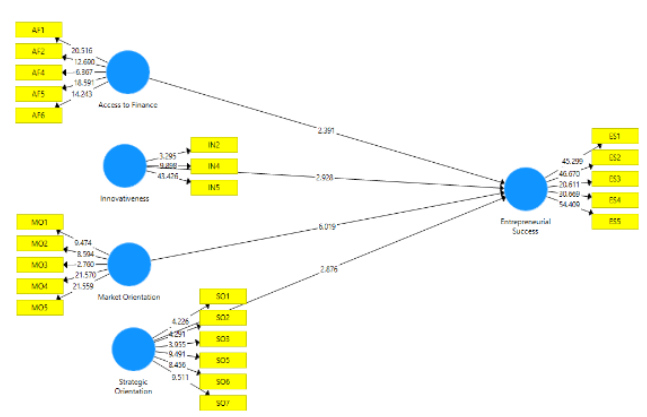

Figure 3: PLS-SEM Bootstrapping Direct Relationship

The results of bootstrapping of the direct relationship between the independent variables and dependent variables are shown that in the figure above all variables are significant at $\mathrm{p}$ values. Finding reveals that H1: There is a significant impact of access to finance on the entrepreneurial success of SMEs, finding shows $(\beta=0.240 ; t=2.391 ; p=0.017)$ therefore it is concluded that $\mathrm{H} 1$ is accepted because the value of $\mathrm{p}$ is less than 0.05 . H2: There is a significant impact of innovativeness on the entrepreneurial success of SMEs, finding shows $(\beta=-0.350$; $\mathrm{t}=2.928 ; \mathrm{p}=0.004$ ) therefore $\mathrm{H} 2$ is also accepted because the value of $\mathrm{p}$ is less than 0.05 . H3 There is a significant impact of market orientation on the entrepreneurial success of SMEs finding reveals that $(\beta=0.617 ; \mathrm{t}=6.019 ; \mathrm{p}=0.000)$ therefore $\mathrm{H} 3$ is also acceptable as the value of $\mathrm{p}$ is less than 0.05 . H4 There is a significant impact of strategic orientation on the entrepreneurial success of SMEs, results reveled that $(\beta=-$ 
$0.196 ; \mathrm{t}=2.876 ; \mathrm{p}=0.004)$ this hypothesis is also accepted as the value of $\mathrm{p}$ is not more than 0.05 .

Table 13: Results of Hypothesis Testing of Direct Relationship

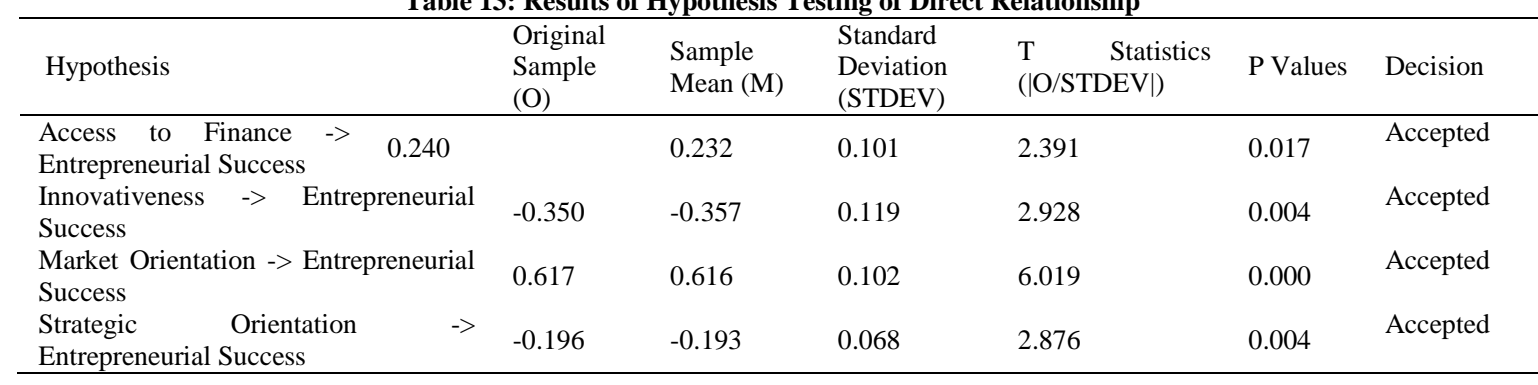

Note: AF: Access to Finance, IN: Innovativeness, MO: Market Orientation, SO: Strategic Orientation, ES: Entrepreneurial Success. The results show in the above table that all hypothesis is accepted as all individual variables ( $\mathrm{AF}, \mathrm{IN}, \mathrm{MO}, \mathrm{SO})$ have significant impact on dependent variable (ES).

Table 14: Summary of Hypothesis Results

\begin{tabular}{lll}
\hline Hypothesis & Hypothesis Statement & Decision \\
\hline H1 & There is a significant impact of access to finance on the & Accepted \\
& Entrepreneurial success of SMEs. & \\
& There is a significant impact of innovativeness on the & Accepted \\
En & $\begin{array}{l}\text { Entrepreneurial success of SMEs. } \\
\text { There is a significant impact of market orientation on the }\end{array}$ & Accepted \\
& Entrepreneurial success of SMEs. & \\
Th: & Entre is a significant impact of strategic orientation on the & Accepted \\
& & \\
\hline
\end{tabular}

\section{Discussion and Conclusion}

These research findings will be in line with the objectives of the study. Moreover, this section reports the overall research findings that also includes the hypothesis results as well.The first objective of the study is to determine the effect of access to finance on the entrepreneurial success to do so firstly, descriptive analysis was conducted and results presented in Table 5 in chapter 4 . The results revealed that for access to finance the value of mean is 3.96 and the value of Standard Deviation shown is 0.988 .

Second objective of the study that is to determine the effect of the Innovativeness on the entrepreneurial success. The results show for Innovativeness the mean value is 3.87 and the value of Standard Deviation is 1.133

A descriptive analysis conducted on market orientation shows that value of mean 3.82 and the value of Standard Deviation of 1.125 .

The mean value of strategic orientation 3.94 and the value of Standard Deviation of 0.961. Similarly, the dependent variable, which is the main objective of the study the value of mean for entrepreneurial success, is 3.87 and the value of Standard Deviation is 1.065 . Hence, all the values are in line with the objective of the study and proved significant.

Therefore, it is concluded that

First hypothesis is accepted as there found a significant and positive relationship between access to finance $(\beta=0.240$; $\mathrm{t}=2.391 ; \mathrm{p}=0.017)$ and entrepreneurial success.

Hypothesis 2 , innovativeness $(\beta=-0.350 ; \mathrm{t}=2.928 ; \mathrm{p}=0.004)$ have significant but negative effect on the entrepreneurial success.

Hypothesis 3 There is a significant impact of market orientation on the entrepreneurial success of SMEs. The results reveal that market orientation $(\beta=0.617 ; \mathrm{t}=6.019 ; \mathrm{p}=0.000)$ has a significant and positive effect of the entrepreneurial success. Hypothesis 4 There is a significant impact of strategic orientation on the entrepreneurial success of SMEs. Strategic Orientation is considered as an important tool for entrepreneurial success. The analysis is carried and results revel that $(\beta=-0.196 ; t=2.876 ; p=0.004)$ strategic orientation has a significant and negative effect on the entrepreneurial success.

\section{References}

i. Abidemi, B. T., Halim, F. B., \& Alshuabi, A. I. (2017). Market orientation and organizational performance: A proposed model on the moderating effect of technological turbulence. Asian Journal of Multidisciplinary Studies, 5(6), 1-7.

ii. Acosta, A. S., Crespo, A. H., \& Agudo, J. C. (2018). Effect of market orientation, network capability and entrepreneurial orientation on international performance of small and medium enterprises (SMEs). International Business Review, 27(6), 1128-1140.

iii. Acs, Z. J., Szerb, L., \& Autio, E. (2016). Global Entrepreneurship and Development Index. Berlin: Springer.

iv. Aftab, M., \& Naveed, T. A. (2013). Role of microfinance institutions in entrepreneurship development in district Gujrat, Pakistan. Journal of Global and Scientific Issues, 1(1), 53-69.

v. Agenor, P. R., \& Canuto, O. (2017). Access to finance, product innovation and middle-income traps. Research in Economics, 71(2), 337-355.

vi. Agier, I., \& Szafarz, A. (2013). Microfinance and gender: Is there a glass ceiling on loan size? World Development, 42(1), 165-181.

vii. Akgun, A. E., \& Keskin, H. (2014). Organisational resilience capacity and firm product innovativeness and performance. International Journal of Production Research, 52(23), 69186937.

viii. Akgun, A. E., Imamoglu, S. Z., Kocoglu, I., Ince, H., \& Keskin, H. (2014). Bridging organizational learning capability and firm performance through customer relationship management. Procedia-Social and Behavioral Sciences, 150(15), 531-540.

ix. Akhtar, I., Ali, Q., \& Cheema, K. U. (2013). Barriers for entrepreneurial ventures in pakistan. Munich Personal RePEc Archive, 1(1), 1-7.

x. Akingunola, R. O. (2011). Small and medium scale enterprises and economic growth in Nigeria: An assessment of financing options. Pakistan Journal of Business and Economic Review, 2(1), 78-97.

xi. Altinay, L., Madanoglu, M., De Vita, G., Arasli, H., \& Ekinci, Y. (2016). The interface between organizational learning capability, entrepreneurial orientation, and SME growth. Journal of Small Business Management, 54(3), 871-891.

xii. Aminu, I. M., \& Shariff, M. N. (2014). Mediating role of access to finance on the relationship between strategic 
orientation and smes performance in Nigeria: A proposed research framework. International Journal of Management Research and Reviews, 4(11), 1023-1035.

xiii. Aminu, I. M., \& Shariff, M. N. (2015). Influence of strategic orientation on SMEs access to finance in Nigeria. Asian Social Science, 11(4), 298-309.

xiv. Andersson, M., \& Lööf, H. (2012). Small business innovation: Firm level evidence from Sweden. The Journal of Technology Transfer, 37(5), 732-754. doi:10.1007/s10961-011-9216-9

Xv. Ar, I. M. (2012). The impact of green product innovation on firm performance and competitive capability: The moderating role of managerial environmental concern. Procedia-Social and Behavioral Science, 62(1), 854-864.

xvi. Arbaugh, J. B., \& Camp, S. M. (2017). Managing growth transitions: Theoretical perspectives and research directions. London: Blackwell.

xvii. Asad, M., Shariff, M. N., \& Alekam, E. M. (2016). Moderating effect of entrepreneurial networking on the relationship between access to finance, entrepreneurial orientaion and performance of micre and small enterprises; A proposed framework. International Journal of Management Studies, $1(1), 50-62$.

xviii. ASEAN. (2014). ASEAN Economic Idicators . Canberra, Australia: ASEAN Department of Foreign Affairs and Trade.

xix. Ata, A. (2018, January 28). The Role of SMEs in Asia's Economic Growth. Retrieved from SME Finance Forum : http://www.smefinanceforum.org/post/the-role-of-smes-inasias-economic-growth

xx. Atuahene Gima, K. (1996). Market orientation and innovation. Journal of business research, 35(2), 93-103

xxi. Augusto, M., \& Coelho, F. (2009). Market orientation and new-to-the-world products: Exploring the moderating effects of innovativeness, competitive strength, and environmental forces. Industrial Marketing Management, 38(1), 94-108.

xxii. Avlonitis, G. J., \& Salavou, H. E. (2007). Entrepreneurial orientation of SMEs, product innovativeness, and performance. Journal of Business Research, 60(5), 566-575.

xxiii. Ayandibu, A. O., \& Houghton, J. (2017). The role of Small and Medium Scale Enterprise in local economic development (LED). Journal of Business and Retail Management Research, 11(2), 131-139.

xxiv. Babajide, A. A. (2015). Effects of microfinance on micro and small enterprises (MSEs) growth in Nigeria. Asian Economic and Financial Review, 2(3), 463-477.

xxv. Bachmann, J. T., Engelen, A., \& Schwens, C. (2016). Toward a better understanding of the association between strategic planning and entrepreneurial orientation-The moderating role of national culture. Journal of International Management, 22(4), 297-315

xxvi. Bagh, T., Arif, M., Liaqat, I., \& Razzaq, S. (2017). Impact of Financial Constraints on Growth and Development of Small and Medium Enterprises in Sialkot Pakistan. International Journal of Financial Markets, 2(4), 131-145.

xxvii. Baker, W. E., \& Sinkula, J. M. (2009). The complementary effects of market orientation and entrepreneurial orientation on profitability in small businesses. Journal of Small Business Management, 47(4), 443-464.

xxviii. Berger, A. N., \& Udell, G. F. (2006). A more complete conceptual framework for SME finance. Journal of Banking \& Finance, 30(11), 2945-2966.

xxix. Berger, A. N., Klapper, L. F., \& Udell, G. F. (1999). The ability of banks to lend to informationally opaque small businesses. The World Bank.

xxx. Blackburn, R. A. (2016). Government, SMEs and entrepreneurship development: Policy, practice and challenges. Abingdon: Routledge.

xxxi. Blazsek, S., \& Escribano, A. (2016). Patent propensity, R\&D and market competition: Dynamic spillovers of innovation leaders and followers. Journal of Econometrics, 191(1), 145163.

xxxii. Bocconcelli, R., Cioppi, M., Fortezza, F., Francioni, B., Pagano, A., Savelli, E., \& Splendiani, S. (2018). SMEs and marketing: a systematic literature review. International Journal of Management Reviews, 20(2), 227-254. xxxiii. Boso, N., Cadogan, J. W., \& Story, V. M. (2013) Entrepreneurial orientation and market orientation as drivers of product innovation success: A study of exporters from a developing economy. International Small Business Journal, 31(1), 57-81.

xxxiv. Brannen, J. (2017). Mixing methods: Qualitative and quantitative research (Vol. 31). Abingdon: Routledge.

xxxv. Branzei, O., \& Vertinsky, I. (2006). Strategic pathways to product innovation capabilities in SMEs. Journal of Business Venturing, 21(1), 75-105.

xxxvi. Brettel, M., Chomik, C., \& Flatten, T. C. (2015). How organizational culture influences innovativeness, proactiveness, and risk-taking: Fostering entrepreneurial orientation in SMEs. Journal of Small Business Management, 53(4), 868-885.

xxxvii. Caglayan, M., \& Demir, F. (2014). Firm productivity, exchange rate movements, sources of finance, and export orientation. World Development, 54(1), 204-219.

xxxviii. Camison, C., \& Villar-Lopez, A. (2014). Organizational innovation as an enabler of technological innovation capabilities and firm performance. Journal of business research, 67(1), 2891-2902.

xxxix. Campello, M. (2006). Debt financing: Does it boost or hurt firm performance in product markets? Journal of Financial Economics, 82(1), 135-172.

xl. Carbo, V. S., Rodriguez-Fernandez, F., \& Udell, G. F. (2016). Trade credit, the financial crisis, and SME access to finance. Journal of Money, Credit and Banking, 48(1), 113-143.

xli. Chahal, H., Dangwal, R. C., \& Raina, S. (2016). Marketing orientation, strategic orientation and their synergistic impact on business performance: A case of SMEs in emerging context (India). Journal of Research in Marketing and Entrepreneurship, 18(1), 27-52.

xlii. Chen, X., Chen, A. X., \& Zhou, K. Z. (2014). Strategic orientation, foreign parent control, and differentiation capability building of international joint ventures in an emerging market. Journal of International Marketing, 22(3), 30-49.

xliii. Cheng, B., Ioannou, I., \& Serafeim, G. (2014). Corporate social responsibility and access to finance. Strategic Management Journal, 35(1), 1-23.

xliv. Cho, Y., \& Honorati, M. (2014). Entrepreneurship programs in developing countries: A meta regression analysis. Labour Economics, 28(1), 110-130.

xlv. Churchill, S. A. (2017). Fractionalization, entrepreneurship, and the institutional environment for entrepreneurship. Small Business Economics, 48(3), 577-597.

xlvi. Clark Jr, P. C. (2013). The effects of multicollinearity in multilevel models. Wright State University.

xlvii. Clauss, T., \& Spieth, P. (2016). Treat your suppliers right! Aligning strategic innovation orientation in captive supplier relationships with relational and transactional governance mechanisms. R\&D Management, 45(3), 1044-1061.

xlviii. Commerce, D. o. (2017). Small and medium-sized enterprises reaching new markets. NewYork: Department of Commerce.

xlix. Cooper, D. R., Schindler, P. S., \& Sun, J. (2006). Business research methods (Vol. 9). New York: McGraw-Hill Irwin: Sage.

1. Covin, J. G., Hornsby, J. S., \& Kuratko, D. F. (2014). Why implementing corporate innovation is so difficult. Business Horizons, 57(5), 647-655.

li. Cowling, M., Liu, W., \& Zhang, N. (2018). Did firm age, experience, and access to finance count? SME performance after the global financial crisis. Journal of Evolutionary Economics, 28(1), 77-100

lii. Dafna, K. (2008). Managerial performance and business success: Gender differences in Canadian and Israeli entrepreneurs. Journal of enterprising communities: People and places in the global economy, 2(4), 300-331.

liii. Dar, M. S., Ahmed, S., \& Raziq, A. (2017). Small and medium-size enterprises in Pakistan: Definition and critical issues. Pakistan Business Review, 19(1), 46-70.

liv. Davidsson, P. (2015). Entrepreneurial opportunities and the entrepreneurship nexus: A re-conceptualization. Journal of Business Venturing, 30(5), 674-695. 
1v. De Luca, L. M., Verona, G., \& Vicari, S. (2010). Market orientation and R\&D effectiveness in High-Technology firms: An empirical investigation in the biotechnology industry. Journal of Product Innovation Management, 27(3), 299-320.

1vi. Demirguc Kunt, A. (2006). Small and medium-size enterprises: Access to finance as a growth constraint. Journal of Banking \& finance, 30(11), 2931-2943.

lvii. Dess, G. G., Ireland, R. D., Zahra, S. A., Floyd, S. W., Janney, J. J., \& Lane, P. J. (2003). Emerging issues in corporate entrepreneurship. Journal of Management, 29(3), 351-378.

lviii. Devece, C., Llopis-Albert, C., \& Palacios-Marques, D. (2017). Market orientation, organizational performance, and the mediating role of crowdsourcing in knowledge-based firms. Psychology \& Marketing, 34(12), 1127-1134.

lix. Dharmasiri, A. S. (2013). Strategic orientation of HR managers in commercial banks in South Asia. International Review of Business Research Papers, 5(6), 121-142.

1x. Didonet, S., Simmons, G., Díaz-Villavicencio, G., \& Palmer, M. (2014). The relationship between small business market orientation and environmental uncertainty. Marketing Intelligence \& Planning, 30(7), 757-779.

1xi. Dincer, O. (. (2018). Does corruption slow down innovation? Evidence from a cointegrated panel of US states. European Journal of Political Economy, 1(1), 465-476.

1xii. Ejdys, J. (2014). Strategic Orientation of Small and Medium Size Enterprises. Economics and Management, 19(4), 346358 .

1xiii. Eniola, A. A. (2017). Entrepreneur-firm characteristics and financing sources. International Journal, 6(2), 13-21.

lxiv. Entrepreneurial orientation in long-lived family firms. (2012). Small Business Economics, 38(1), 67-84.

1xv. Eric M. Olson, Orville C. Walker, \& Ruekert, J. a. (2003). The impact of communication strategy on launching new products: The moderating role of product innovativeness. Journal of Product Innovation Management, 20(1), 4-21.

lxvi. Evans, N., Bosua, R., \& Fourie, L. (2016). The challenges and mindset limitations impacting innovation in manufacturing SMEs in regional Australia. ICIE2016-Proceedings of the 4th International Conference on Innovation and Entrepreneurship (pp. 417-430). Australia: Academic Conferences and publishing limited.

1xvii. Fahy, J. (2000). The Resource-Based View of the Firm: Some Stumbling-Blocks on The Road to Understanding Sustainable Competitive Advantage. Journal of European Industrial Training, 24(2/3/4), 94-104.

1xviii. Ferraresi, A. A., Quandt, C. O., dos Santos, S. A., \& Frega, J. R. (2012). Knowledge management and strategic orientation: leveraging innovativeness and performance. Journal of Knowledge Management, 16(5), 688-701.

1xix. Fouzdar, K. S., \& Sachdev, P. (2017). Factors affecting success of entrepreneurial ventures. Asian Journal of Multidimensional Research , 6(9), 38-47.

1xx. Frambach, R. T., Fiss, P. C., \& Ingenbleek, P. T. (2016). How important is customer orientation for firm performance? A fuzzy set analysis of orientations, strategies, and environments. Journal of Business Research, 69(4), 14281436.

1xxi. Fraser, S., Bhaumik, S. K., \& Wright, M. (2015). What do we know about entrepreneurial finance and its relationship with growth? International Small Business Journal, 33(1), 70-88.

1xxii. Frazer, G. (2005). Which firms die? A look at manufacturing firm exit in Ghana. Economic Development and Cultural Change, 53(3), 585-617.

lxxiii. Freund, C., Hufbauer, G. C., \& Jung, E. (2016). Enhancing Export Opportunities for Small and Medium-Sized Enterprises. Washington, DC: Peterson Institute for International Economics.

lxxiv. Ghimire, B., \& Abo, R. (2013). An empirical investigation of Ivorian SMEs access to bank finance: Constraining factors at demand-level. Journal of Finance And Investment Analysis, 2(4), 29-55.

lxxv. Giannetti, M., \& Ongena, S. (2009). Financial integration and firm performance: Evidence from foreign bank entry in emerging markets. Review of Finance, 13(2), 181-223. 1xxvi. Gomez, R., Perez, J. G., Lopez Martin, M. D., \& Garcia, C. G (2016). Collinearity diagnostic applied in ridge estimation through the variance inflation factor. Journal of Applied Statistics, 43(10), 1831-1849.

1xxvii. Gounaris, S., \& Siampos, A. (2015). Market and entrepreneurial orientation's effect on organisational performance through marketing capabilities. Conference Proceedings. Academy of Marketing.5, pp. 55-76. Ireland: Limerick

1xxviii. Greenley, G. E., Hooley, G. J., \& Rudd, J. M. (2005). Market orientation in a multiple stakeholder orientation context: implications for marketing capabilities and assets. Journal of Business Research, 58(11), 1483-1494.

1xxix. Gupta, R., \& Basu, S. (2014). Influence of Dimensions of Strategic Orientation on the Growth of Small Firms and Resources as Moderating Variables. Management and Labour Studies, 39(4), 461-476.

1xxx. Hair Jr, J. F., Wolfinbarger, M., Money, A. H., Samouel, P., \& Page, M. J. (2015). Essentials of business research methods. Abingdon: Routledge.

1xxxi. Hair Jr, J., Sarstedt, M., Hopkins, L., \& G. Kuppelwieser, V. (2014). Partial least squares structural equation modeling (PLS-SEM) An emerging tool in business research. European Business Review, 26(2), 106-121.

lxxxii. Hair, J. F., Anderson, R. E., Tatham, R. L., \& William, C. (1986). Black (1995),Multivariate Data Analysis. New York: Macmillan.

lxxxiii. Hair, J. F., Sarstedt, M., Ringle, C. M., \& Mena, J. A. (2014). An assessment of the use of partial least squares structural equation modeling in marketing research. Journal of the Academy Of Marketing Science, 40(3), 414-433.

lxxxiv. Hakala, H. (2015). Strategic orientations in management literature: three approaches to understanding the interaction between market, technology, entrepreneurial and learning orientations. International Journal of Management Reviews, 13(2), 199-217.

lxxxv. Hakala, H., \& Kohtamäki, M. (2011). Configurations of entrepreneurial-customer-and technology orientation: Differences in learning and performance of software companies. International Journal of Entrepreneurial Behavior \& Research, 17(1), 64-81.

lxxxvi. Haroon, U., \& Shariff, M. N. (2016). The interplay of innovation, TQM practices and SMEs performance in Pakistan: moderating effects of knowledge inertia and external environment. South East Asia Journal of Contemporary Business, Economics and Law, 9(2), 57-62.

1xxxvii. Hartanto, W., Wahyudi, S., \& Sugiarto, Y. (2017). Analysis the effect of entrepreneurial orientations and adaptation of external environment to SMEs performance with competitive advantages as intervening variables (study on SMEs fashion sector in semarang. Diponegoro University.

lxxxviii. Hayami, Y. (2009). Social capital, human capital and the community mechanism: Toward a conceptual framework for economists. The Journal of Development Studies, 45(1), 96123.

lxxxix. Henseler, J., Ringle, C. M., \& Sarstedt, M. (2015). A new criterion for assessing discriminant validity in variance-based structural equation modeling. Journal of The Academy of Marketing Science, 43(1), 115-135.

xc. Herath, H. A., \& Mahmood, R. (2013). Strategic orientation based research model of SME performance for developing countries. Review of Integrative Business and Economics Research, 2(1), 430-449.

xci. Hillman, A. J., Withers, M. C., \& Collins, B. J. (2009). Resource Dependence Theory: A Review. Journal of Management, 35(6), 1404-1427.

xcii. Hinson, R. E., \& Mahmoud, M. A. (2011). Qualitative insights into market orientation in small Ghanaian businesses. International Journal of Marketing Studies, 3(1), 35-45.

xciii. Ho, K. L., Nguyen, C. N., Adhikari, R., Miles, M. P., \& Bonney, L. (2018). Exploring market orientation, innovation, and financial performance in agricultural value chains in emerging economies. Journal of Innovation \& Knowledge, 3(3), 154-163. 
xciv. Hong, J., Song, T. H., \& Yoo, S. (2013). Paths to Success: How Do Market Orientation and Entrepreneurship Orientation Produce New Product Success? Journal of Product Innovation Management, 30(2), 44-55.

xcv. Hopkins, V. (2016). Institutions, incentives, and policy entrepreneurship. Policy Studies Journal, 44(3), 332-348.

xcvi. Hoq, M. Z., \& Chauhan, A. A. (2013). Effects of organizational resources on 373 organizational performance: an empirical study of smes. Interdisciplinary Journal of Contemporary Research in Business, 2(12), 373-385.

xcvii. Hult, G. T., \& Ketchen, D. J. (2017). Disruptive marketing strategy. AMS Review, 7(1), 20-25.

xcviii. Hussain, D., \& Yaqub, M. (2010). Micro-Entrepreneurs Motivations, Success Factors, and Challenges. International Research Journal of Finance and Economics, 56(1), 22-28.

xcix. Hyder, S., \& Lussier, R. N. (2016). Why businesses succeed or fail: A study on small businesses in Pakistan. Journal of Entrepreneurship in Emerging Economies, 8(1), 82-100.

c. Ibrahim, A. B., \& Goodwin, J. R. (1986). Perceived causes of success in small business. American Journal of Small Business, 11(2), 41-50

ci. Indris, S., \& Primiana, I. (2015). Internal and external environment analysis on the performance of small and medium industries (Smes) in Indonesia. International journal of scientific \& technology research, 4(4), 188-198.

cii. Jabeen, R., Aliyu, M. S., \& Mahmood, R. (2016). The Moderating Effect of External Environment on the Relationship Between Market Orientation and Business Performance: A Quantitaitve Approach. International Post Graduate Business Journal, 8(1), 16-25.

ciii. Jane, S., \& Zubin, A. (2015). Qualitative research: Data collection, analysis and management. The Canadian Journal of Hospital Pharmacy, 68(3), 228-231.

civ. Jogaratnam, G. (2017). The effect of market orientation, entrepreneurial orientation and human capital on positional advantage: Evidence from the restaurant industry. International Journal of Hospitality Management, 60(1), 104113.

cv. Joseph, O. O., \& Francis, K. (2015). The influence of organizational culture and market orientation on performance of microfinance institutions in Kenya. International Journal of Business and Management, 10(8), 204.

cvi. Juhdi, N. H., Hong, T. S., \& Juhdi, N. (2015). Market Orientation and Entrepreneurial Success: Mediating Role of Entrepreneurial Learning Intensity. Jurnal Pengurusan (UKM Journal of Management), 43(1), 27-36.

cvii. Junkunc, M. T. (2007). Managing radical innovation: The importance of specialized knowledge in the biotech revolution. Journal of Business Venturing, 22(3), 388-411.

cviii. Jyoti, J., \& Sharma, J. (2014). Impact of market orientation on business performance: Role of employee satisfaction and customer satisfaction. Vision Journal, 16(4), 297-313.

cix. Kamasak, R. (. (2015). Determinants of innovation performance: a resource-based study. Procedia-Social and Behavioral Sciences, 195(8), 1330-1337.

cx. Kara, A., Spillan, J. E., \& DeShields, O. W. (2005). The effect of a market orientation on business performance: A study of small-sized service retailers using MARKOR scale. Journal of small business management, 43(2), 105-118.

cxi. Karadag, H. (2017). The impact of industry, firm age and education level on financial management performance in small and medium-sized enterprises (SMEs) Evidence from Turkey. Journal of Entrepreneurship in Emerging Economies, 9(3), 300-314.

cxii. Kellermanns, F. W., Eddleston, K. A., Sarathy, R., \& Murphy, F. (2012). Innovativeness in family firms: A family influence perspective. Small Business Economics, 38(1), 85-101.

cxiii. Kelley, D. J., Singer, S., \& Herrington, M. (2012). Global entrepreneurship monitor 2011 global report. London: Global Entrepreneurship Research Association.

cxiv. Kelley, K., Clark, B., Brown, V., \& Sitzia, J. (2003). Good practice in the conduct and reporting of survey research. International Journal for Quality in Health Care, 15(3), 261266. cxv. Khan. (2015). Impact of sources of finance on the growth of SMEs: evidence from Pakistan. Decision, 42(1), 3-10.

cxvi. Khan, M. (2015). Scenario of Manufacturing Pharmaceutical Small and Medium Enterprises (SMEs) in Pakistan. International Journal of Business Management and Economic Studies, 1(1), 14-20.

cxvii. Khan, M. W., \& Khalique, M. (2014). An overview of small and medium enterprises in Malaysia and Pakistan: past, present and future scenario. Business and Management Horizons, 2(2), 38-49.

cxviii. Kocak, A., Carsrud, A., \& Oflazoglu, S. (2017). Market, entrepreneurial, and technology orientations: impact on innovation and firm performance. Management Decision, 55(2), 248-270.

cxix. Krejcie, R. V., \& Morgan, D. W. (1970). Determining sample size for research activities. Educational and Psychological Measurement, 30(3), 607-610.

cxx. Kropp, F., Lindsay, N. J., \& Shoham, A. (2006). Entrepreneurial, market, and learning orientations and international entrepreneurial business venture performance in South African firms. International Marketing Review, 23(5), 504-523.

cxxi. Kumar, R., Singh, R. K., \& Shankar, R. (2015). Critical success factors for implementation of supply chain management in Indian small and medium enterprises and their impact on performance. IIMB Management review, 27(2), 92104.

cxxii. Kumar, S., \& Rao, P. (2015). A conceptual framework for identifying financing preferences of SMEs. Small Enterprise Research, 22(1), 99-112.

cxxiii. Kuratko, D. F. (2009). Introduction to entrepreneurship. South-Western: Australia and UK:.

cxxiv. Kuratko, D. F. (2015). Corporate entrepreneurship: Accelerating creativity and innovation in organizations. The Oxford Handbook of Creativity, Innovation and Entrepreneurship, 1(1), 477-488.

cxxv. Kuratko, D. F. (2016). Entrepreneurship: Theory, process, and practice. Cengage Learning.

cxxvi. Kwaning, C. O., Nyantakyi, K., \& Kyereh, B. (2015). The challenges behind smes' access to debts financing in the Ghanaian financial market. International Journal of Small Business and Entrepreneurship Research, 3(2), 16-30.

cxxvii. Lampard, R., \& Pole, C. (2015). Practical social investigation: Qualitative and quantitative methods in social research. Abingdon: Routledge.

cxxviii. Ledwith, A., \& O'Dwyer, M. (2009). Market orientation, NPD performance, and organizational performance in small firms. Journal of Product Innovation Management, 26(6), 652-661.

cxxix. Lee, C. (2015). Innovation, entrepreneurship, and business performance: a mixed methods study of the Australian restaurant sector. University of South Australia: Doctoral dissertation, University of South Australia.

cxxx. Lee, N., Sameen, H., \& Cowling, M. (2015). Access to finance for innovative SMEs since the financial crisis. Research policy, 44(2), 370-380.

cxxxi. Lemon, K. N., \& Verhoef, P. C. (2016). Understanding customer experience throughout the customer journey. Journal of Marketing, 80(6), 69-96.

cxxxii. Li, L., Qian, G., \& Qian, Z. (2015). Should Small, Young Technology-Based Firms Internalize Transactions in Their Internationalization? Entrepreneurship Theory and Practice, 39(4), 839-862.

cxxxiii. Liao, S., Chang, W., Wu, C., \& Katrichis, J. M. (2011). A Survey of Market OrientationResearch (1995 - 2008). Industrial Marketing Management, 40(2), 301-310.

cxxxiv. Lockett, A., \& Thompson, S. (2001). The Resource-Based View and Economics. Journal of Management, 27(6), 723754.

cxxxv. Long, D., \& Dong, N. (2017). The effect of experience and innovativeness of entrepreneurial opportunities on the new venture emergence in China. Journal of Entrepreneurshipin Emerging Economies, 9(1), 21-34. doi:10.1108/JEEE-042016-0014

cxxxvi. Lonial, S. C., \& Carter, R. E. (2015). The impact of organizational orientations on medium and small firm 
performance: A resource-based perspective. Journal of Small Business Management, 53(1), 94-113.

cxxxvii. Lynee, L., \& Letiziza, G. (2011). The Role of Researcher. In L. G. Lynee, \& G. Letiziza, Scholarly publication in a changing academic landscapes: Models for success (pp. 6989). New York: Palgrave Macmillan.

cxxxviii. Madanchian, M., Hussein, N., Noordin, F., \& Taherdoost, H. (2015). The role of SMEs in economic development: Case study of Malaysia. International Journal of Academic Research in Management, 4(3), 77-84.

cxxxix. Mahmood, N., Jamil, F., Munir, H., Yasir, N., \& Cai Jianfeng. (2017). Business incubators and challenges: evidences from Pakistan. American Scientific Publishers, 23(9), 8479-8483.

cxl. Maksimov, V., Wang, S. L., \& Luo, Y. (2017). Reducing poverty in the least developed countries: The role of small and medium enterprises. Journal of World Business, 52(2), 244257.

cxli. Maloney, W. F. (2004). Informality revisited. World Development, 32(7), 1159-1178.

cxlii. Margaritis, D., \& Psillaki, M. (2010). Capital structure, equity ownership and firm performance. Journal of Banking \& Finance, 34(3), 621-632.

cxliii. Martinez, R. J., \& Romero, I. (2017). Determinants of innovativeness in SMEs: Disentangling core innovation and technology adoption capabilities. Review of Managerial Science, 11(3), 543-569.

cxliv. Massiera, P., Gilmore, A., \& Sellami, M. (2018). Marketing illegitimacy within SMEs: learning triggers and influence on marketing communications. Journal of Strategic Marketing, 26(8), 688-701.

cxlv. Matsuno, K., \& Mentzer, J. T. (2015). Market orientation: Reconciliation of two conceptualizations. In Proceedings of the 1995 Academy of Marketing Science (AMS) Annual Conference.1, pp. 49-55. Cham: Springer

cxlvi. Matzler, K., Veider, V., Hautz, J., \& Stadler, C. (2015). The impact of family ownership, management, and governance on innovation. Journal of Product Innovation Management, 32(3), 319-333

cxlvii. McGrath, R. G. (2001). Exploratory learning, innovative capacity, and managerial oversight. Academy of Management Journal, 44(1), 118-131.

cxlviii. McGuinness, G., \& Hogan, T. (2016). Bank credit and trade credit: Evidence from SMEs over the financial crisis. International Small Business Journal, 34(4), 412-445.

cxlix. McKenny, A. F., Short, J. C., Ketchen Jr, D. J., Payne, G. T., \& Moss, T. W. (2018). Strategic entrepreneurial orientation: Configurations, performance, and the effects of industry and time. Strategic Entrepreneurship Journal, 12(4), 504-521.

cl. Mersha, D., \& Ayenew, Z. (2017). Determinants of access to formal financial sources of micro and small enterprises (mses) in west oromia region, Ethiopia. International Journal of Business and Economics Research, 6(5), 100-112.

cli. Mir, S. U., Naimi, N. b., \& Rosylin, B. M. (2016). Are small and medium enterprises (SMEs) failing at the rate suggested in prior studies? An analysis of the degree of financial stress on small and medium enterprises and its impact on their life expectancy. Internation Business Management, 10(18), 42584267.

clii. Mohammed, U. D., \& Obeleagu-Nzelibe, C. G. (2014). Entrepreneurial skills and profitability of Small and Medium Enterprises (SMEs): Resource acquisition strategies for new ventures in Nigeria. In Proceedings of 25th International Business Research Conference.64, pp. 1-21. International Business Research Conference.

cliii. Morris, M. H., Kuratko, D. F., \& Covin, J. G. (2013). Corporate entrepreneurship \& innovation. Chicago: Cengage Learning.

cliv. Moulton, S., \& Sandfort, J. R. (2017). The strategic action field framework for policy implementation research. Policy Studies Journal, 45(1), 144-169.

clv. Mu, J., \& Di Benedetto, C. A. (2011). Strategic orientations and new product commercialization: mediator, moderator, and interplay. R\&D Management, 41(4), 337-359. clvi. Mukherjee, K. (2016). The psychology of the successful entrepreneur. International Journal of Advanced Engineering and Management, 1(1), 25-32.

clvii. Mukumba, T. (2014). Overcoming SMEs challenges through critical success factors: A case of SMEs in the Western Cape Province, South Africa. Economic \& Business Review, 16(1), 21-32.

clviii. Mustaghis-ur-Rahman, R. R., \& Jalees, T. (2015). The Effectiveness of Support Policies for SMEs in Pakistan: A study of Karachi Based SME. Pakistan Business Review, 1(1), 829-857.

clix. Narver, J. C., \& Slater, S. F. (1990). The effect of a market orientation on business profitability. The Journal of Marketing, 1(1), 20-35.

clx. Ngah, R., \& Salleh, Z. (2015). Emotional intelligence and entrepreneurs' innovativeness towards entrepreneurial success: A preliminary study. American Journal of Economics, 5(2), 285-290.

clxi. Nikraftar, T., \& Momeni, S. (2017). The effects of entrepreneurial orientation, market orientation and learning orientation on performance of ICT business. International Journal of Management Concepts and Philosophy, 10(4), 378391.

clxii. Niskanen, J., Piispanen, V. V., \& Montonen, T. (2017). Business models for research-based spin-offs: the strategic entrepreneurship perspective. International Journal of Knowledge Management Studies, 8((1-2)), 38-53.

clxiii. Ogunsiji, A. S., \& Ladanu, W. K. (2017). A Theoretical Study of Performance Measures in the Strategic and Corporate Entrepreneurship of Firms. International Journal of Life Sciences (IJLS), 1(1), 49-57.

clxiv. Ozkaya, H. E., Hult, G. T., Calantone, R., \& Droge, C. (2015). Antecedents and consequences of marketing and innovation competence: does orientation matter? In Ideas in Marketing: Finding the New and Polishing the Old. (pp. 447-456). Cham: Springer.

clxv. Pakistan Economic Survey. (2017). Pakistan Economic Survey 16-17. Goverment of Pakistan-Ministry of Finance. Retrieved from http://www.finance.gov.pk/survey_1617.html

clxvi. Pakistan, S. B. (2016, May 6). Infrastructure, Housing \& SME Finance Department. Karachi, Sindh, Pakistan.

clxvii. Palmie, M., Zeschky, M., Winterhalter, S., Sauter, P. W., Haefner, N., \& Gassmann, O. (2016). Coordination mechanisms for international innovation in SMEs: effects on time-to-market and R\&D task complexity as a moderator. Small Business Economics, 46(2), 273-294.

clxviii. Pandula, G. (2011). An empirical investigation of small and medium enterprises' access to bank finance: The case of an emerging economy. In Proceedings of ASBBS Annual Conference (pp. 18-28). ASBBS.

clxix. Patricia, I., \& Lawrence, R. (2015). Are we there yet? Data saturation in qualitative research. The Qualitative Report, 20(9), 1408-1416.

clxx. Perez, E. H., \& Canino, R. M. (2009). The importance of the entrepreneur's perception of "success". Review of International Comparative Management, 10(5), 990-1010.

clxxi. Perez-Luno, A., Saparito, P., \& Gopalakrishnan, S. (2016). Small and Medium-Sized Enterprise's Entrepreneurial versus Market Orientation and the Creation of Tacit Knowledge. Journal of Small Business Management, 54(1), 262-278.

clxxii. Pérez-Luño, A., Wiklund, J., \& Cabreraa, R. V. (2011). The dual nature of innovative activity: How entrepreneurial orientation influences innovation generation and adoption. Journal of Business Venturing, 26(5), 555-571. doi:10.1016/j.jbusvent.2010.03.001

clxxiii. Perren, L., \& Grant, P. (2000). The evolution of management accounting routines in small businesses: a social construction perspective. Management Accounting Research, 11(4), 391411.

clxxiv. Prajogo, D. I. (2016). The strategic fit between innovation strategies and business environment in delivering business performance. International Journal of Production Economics, 171(2), 241-249. 
clxxv. Preffer, J., \& Salancik, G. (1978). The External Control of Organizations: A Resource Dependence Perspective. New York: Harper \& Row.

clxxvi. Pulendran, S., Speed, R., \& Widing, R. (2015). Marketing Planning, Market Orientation and Performance: An Empirical Study of Australian Organisations. In Proceedings of the 1998 Academy of Marketing Science (AMS) Annual Conference (pp. 455-456). Chicago: Springer.

clxxvii. Pulka, B. M., Ramli, A. B., \& Bakar, M. S. (2018, January). Marketing capabilities, Resources acquisition capabilities, Risk management capabilities, Opportunity recognition capabilities and SMEs performance: A proposed framework. Asian Journal of Multidisciplinary Studies, 6(1), 12-22. Retrieved https://www.researchgate.net/publication/322159822

clxxviii. Quartey, P., Turkson, E., Abor, J. Y., \& Iddrisu, A. M. (2017). Financing the growth of SMEs in Africa: What are the contraints to SME financing within ECOWAS? Review of Development Finance, 7(1), 18-28.

clxxix. Rahaman, M. M. (2011). Access to financing and firm growth. Journal of Banking \& Finance, 35(3), 709-723.

clxxx. Ramayah, T., Samat, N., \& Lo, M. C. (2011). Market orientation, service quality and organizational performance in service organizations in Malaysia. Asia-Pacific Journal of Business Administration, 3(1), 8-27.

clxxxi. Ramesh, R. S., \& Ramesh, S. (2014). Impact of Market Orientation on SMEs Business Performance An Empirical Study of Select SMEs in Bangalore. International Journal of Research in Management, Social Science and Technology, 8(8), 1-13.

clxxxii. Reijonen, H., \& Komppula, R. (2010). The adoption of market orientation in SMEs: required capabilities and relation to success. Journal of Strategic Marketing, 18(1), 19-37.

clxxxiii. Rey-Marti, A., Ribeiro-Soriano, D., \& Sanchez-Garcia, J. L. (2016). Giving back to society: Job creation through social entrepreneurship. Journal of Business Research, 69(6), 2067 2072.

clxxxiv. Riding, A., Madill, J., \& Haines, G. (2007). Incrementality of SME loan guarantees. Small Business Economics, 29((1-2)), 47-61.

clxxxy. Rogo, H. B., Shariff, M. N., \& Hafeez, M. H. (2017). Moderating Effect of Access to Finance on the Relationship between Total Quality Management, Market Orientation and Small and Medium Enterprises Performance: A Proposed Framework. International Review of Management and Marketing, 7(1), 119-127.

clxxxvi. Sarfraz, A. (2018, 10 25). Strengthening Entrepreneurship . Retrieved from Business Recorder: https://fp.brecorder.com/2018/08/20180826401861/

clxxxvii. Sekaran, U., \& Bougie, R. (2016). Research methods for business: A skill building approach (Vol. 59). New Jersey: John Wiley \& Sons.

clxxxviii. Sezen, B., \& Cankaya, S. Y. (2013). Effects of green manufacturing and eco-innovation on sustainability performance. Procedia-Social and Behavioral Sciences, 99(6), 154-163.

clxxxix. Shabbir, M. S., Shariff, M. N., Alshaibani, Y. H., Faisal, M., \& Salman, R. (2018). Entrepreneurship and skills development for socioeconomic growth; present landscape and future agenda for Pakistan. Academy of Entrepreneurship Journal, 24(3), 1-12.

cxc. Shah, N., \& Soomro, B. A. (2017). Investigating entrepreneurial intention among public sector university students of Pakistan. Education+ Training, 59((7/8)), 841-855.

cxci. Shamsudeen, K., Keat, O., \& Hassan, H. (2015). Relationship between Some Determinants of SMEs Performance in Nigeria: A Pilot Test. International Journal of Management Research \& Review, 5(10), 957-963.

cxcii. Shane, S. (2008). The importance of angel investing in financing the growth of. Retrieved from entrepreneuria ventures: [Online] Available: http:

cxciii. Shari, L. (2012). Sample size policy for qualitative studies using in-depth interviews. Springer, 1319-1320.

cxciv. Shaw, G., \& Pretorius, M. (2004). Business plans in bank decision-making when financing new ventures in South
Africa. South African Journal of Economic and Management Sciences, 7(2), 221-241.

cxcv. Shehu, A. M. (2014). The relationship between market orientation and firm performance: A look at Nigerian SMEs. Developing Country Studies, 4(12), 87-93.

cxcvi. Shoham, A., \& Lev, S. (2015). The Miles and Snow Strategic Typology and its Performance Implications. In Global Perspectives in Marketing for the 21st Century (pp. 214-220). Cham: Springer.

cxcvii. SMEDA. (2016, December 20). State of SMEs in Pakistan. Retrieved from http://www.smeda.org.com.pk: http://www.smeda.org/index.php?option=com_content\&view $=$ article \&id $=7$ : state-of-smes-in-pakistan\&catid $=15$

cxcviii. SMEDA. (2017). State of SMEs in Pakistan. Smeda. Retrieved from State of SMEs in Pakistan: https://smeda.org/index.php?option=com_content\&view=arti cle\&id=7: state-of-smes-in-pakistan \&catid $=15$

cxcix. Sok, P. O. (2016). The performance advantages for SMEs of product innovation and marketing resource-capability complementarity in emerging economies. Journal of Small Business Management, 54(3), 805-826.

cc. Solongo, G. (2017). Financial resources management for smes of mongolia. International Business Research, 10(6), 145-153.

cci. Sui, S., \& Baum, M. (2014). Internationalization strategy, firm resources and the survival of SMEs in the export market. Journal of International Business Studies., 45(7), 821-841.

ccii. Taormina, R. J., \& Kin-Mei Lao, S. (2007). Measuring Chinese entrepreneurial motivation: Personality and environmental influences. International Journal of Entrepreneurial Behavior \& Research, 13(4), 200-221.

cciii. Teece, D. J., Pisano, G., \& Shuen, A. (1997). Dynamic capabilities and strategic management. Strategic Management Journal, 18(7), 509-533

cciv. Tomas, M. H., Hurley, F. R., \& Gary, A. K. (2004). Innovativeness: Its antecedents and impact on business performance. Industrial Marketing Management, 33(5), 429438.

ccv. Uhlaner, L. M., van Stel, A., Duplat, V., \& Zhou, H. (2013). Disentangling the Effects of Organizational Capabilities, Innovation and Firm Size on SME Sales Growth. Small Business Economics, 41(3), 581-607.

ccvi. Uit Beijerse, R. P. (1999). Questions in Knowledge Management: Defining and Conceptualising a Phenomenon. Journal of Knowledge Management, 3(2), 94-110.

ccvii. Ullah, H., Shah, B., Hassan, F. S., \& Zaman, T. (2011). Environment related factors affecting the entrepreneurial orientation: Evidence from Khyber Pakhtunkhwa-Pakistan. International Journal of Education and Social Sciences, 1(1), 1-19.

ccviii. Ullah, M. S., Naimi, N. B., \& Yusoff, R. B. (2016). The impact of entrepreneurs' levels of education, age and years in business on their decision to obtain finance for small and medium enterprises (smes) from rotating savings and credit associations (roscas) in lahore. The Social Sciences, 11(13), 3252-3256.

ccix. Uwe, F. (2014). An Introduction to Qualitative Research. London: SAGE Publications.

ccx. van Oostrom, M., \& Fernandez-Esquinas, M. (2017). Exploring the links between culture and innovation in micro firms: cultural dimensions, social mechanisms and outcomes. European Planning Studies, 25(11), 1932-1953.

ccxi. Venkatraman, N. (1989). Strategic orientation of business enterprises: The construct, dimensionality, and measurement. Management science, 35(8), 942-962.

ccxii. Voorhees, C. M., Brady, M. K., Calantone, R., \& Ramirez, E. (2016). Discriminant validity testing in marketing: an analysis, causes for concern, and proposed remedies. Journal of the Academy of Marketing Science, 44(1), 119-134.

ccxiii. Wamahiga, T. S. (2014). Organizational factors affecting growth and sustainability of construction companies. United States International University Africa.

ccxiv. Wang, T. (2009). Distinguishing and linking entrepreneurial intention and action . Canada: The University of Western Ontario. 
ccxv. Wassmann, S., Kramer, C., Schmicker, S., Deml, B., Topperwien, S., \& Forster, M. (2016). Assessing and increasing innovativeness of SMEs in the context of their demographic development. In Advances in Ergonomic Design of Systems, Products and Processes.27, pp. 27-41. Vieweg, Berlin, Heidelberg.: Springer doi:10.1016/j.jbusvent.2010.07.001

ccxvi. Watson, K., Hogarth-Scott, S., \& Wilson, N. (1998). Smal business start-ups: success factors and support implications. International Journal of Entrepreneurial Behavior \& Research, 4(3), 217-238.

ccxvii. Wehinger, G. (2014). SMEs and the credit crunch. OECD Journal: Financial Market Trends, 2(1), 115-148.

ccxviii. Wernerfelt, B. (1984). A resource-based view of the firm. Strategic Management Journal, 5(2), 171-180.

ccxix. Whittaker, D. H., Fath, B. P., \& Fiedler, A. (2016). Assembling capabilities for innovation: Evidence from new zealand SMEs. International small business journal, 34(1), 123-143.

ccxx. Wolff, J. A., Pett, T. L., \& Ring, J. K. (2015). Small firm growth as a function of both learning orientation and entrepreneurial orientation: An empirical analysis. International Journal of Entrepreneurial Behavior \& Research, 21(5), 709-730.

ccxxi. World Bank (IBRD). (2018). Doing business. New York, USA: The World Bank. Retrieved from http://www.doingbusiness.org/en/data/exploreeconomies/pak istan

ccxxii. Xavier, S. R., Kelly, D., Kew, J., Herrington, M., \& Vorderwülbecke, A. (2013). The Global EntrepreneurshipMonitor Report. London.

ccxxiii. Yan, H., He, X., \& Cheng, B. (2017). Managerial Ties, Market Orientation, and Export Performance: Chinese Firms Experience-ADDENDUM. Management and Organization Review, 13(3), 639-641.

ccxxiv. Yazdanfar, D., \& Ohman, P. (2018). Growth and job creation at the firm level: Swedish SME data. Management Research Review, 41(3), 345-358.

ccxxv. Zafar, A., \& Mustafa, S. (2017). SMEs and its role in economic and socio-economic development of Pakistan. International Journal of Academic Research in Economics and Management Sciences, 7(4), 195-205.

ccxxvi. Zahra, S. A., \& Bogner, W. C. (2000). Technology strategy and software new ventures' performance: Exploring the moderating effect of the competitive environment. Journal of Business Venturing, 15(2), 135-173.

ccxxvii. Zampetakis, L. A., Gruys, M. L., \& Dewett, T. (2014). Ideas and Implementation: The Effective Implementation of Novel Marketing Programmes in Small-to Medium-Sized Greek Firms. Creativity and Innovation Management, 23(2), 168182.

ccxxviii. Zanetsie, A. M., Adomah, A. A., Chongsi, M. E., NgemeNdie, M. E., \& Faes, C. (2016). Multivariate Normality Assessment. Hasselt University.

ccxxix. Zellweger, T., \& Sieger, P. (2012). Entrepreneurial orientation in long-lived family firms. Small Business Economics, 38(1), 67-84. doi:10.1007/s11187-010-9267-6

ccxxx. Zhao, Y., Qin, Y., Zhao, X., \& Shi, L. (2018). Relationship between entrepreneurial motivation and crowdfunding success based on qualitative analysis-based on kickstarer website data. Wireless Personal Communications, 102(2), 1723-1734.

ccxxxi. Zhineng, L. (2012). Entrepreneurial alertness: An exploratory study. Berlin: Springer.

ccxxxii. Zhou, K. Z., Yim, C. K., \& Tse, D. K. (2005). The effects of strategic orientations on technology-and market-based breakthrough innovations. Journal of Marketing, 69(2), 42-60.

ccxxxiii. Zotorvie, J. S. (2017). A study of Financial Accounting Practices of Small and Medium Scale Enterprises (SMEs) in Ho Municipality, Ghana. International Journal of Academic Research in Business and Social Sciences, 7(7), 29-39. 